\title{
低炭素鋼板の高周波焼入れによる高強度化*
}

\section{Strengthening of Low Carbon Steel Sheet Using Rf Induction Heat Quenching}

Tsunetaka SUMOMOGI*1 , Etsunori FUJITA, Masayoshi NAKAMURA, Yumi OGURA and Masanobu OHMORI

\author{
${ }^{* 1}$ Hiroshima Kokusai Gakuin Univ. Faculty of Engineering \\ Nakano 6-20-1, Aki-ku, Hiroshima, 739-0321 Japan
}

Low carbon steel without any alloying elements which enhance the quench hardening has not been considered as a material fitting for quenching. In the present study, however, the quench strengthening was found to occur fully in the sheet of the low carbon steel after the sheet was rapidly cooled in rf induction heat quenching. This finding shows the possibility of a combined process of press forming and quenching. In this process, for example, an automobile part which is press formed severely with the steel sheet of good formability is thought to be increased in strength by the induction heat quenching performed in the suitable segments on the part.

Key Words : Low Carbon Steel Sheet, Quench Hardening, Rf Induction Heat, Press Forming

\section{1. 緒言}

自動車の軽量化には，主要構造部材である鋼を可能な限りより軽い代替材料に変更するとともに，鋼部材その ものの寸法（板の厚さ, パイプの肉厚など）を極力小さくすることが求められる. この手段として, 強度の小さ い低炭素鋼の代わりに高強度鋼を使用することが現下の趨勢になっている(1). ただし，高強度鋼の使用に伴って 成形性の低下やスプリングバックの増大など, 加工上の困難が大きくなることは避けられない(2).

著者の一人（藤田）は，約 30 年前，ある自動車部品製造工場でプレス加工した自動車用薄鋼板（低炭素鋼板） に点溶接機（スポット・ウェルダー）で通電加熱してのち水冷却していることを目撃したことがある. 作業者に よれば，そうすることによって鋼板を強くすることができるとのことであった．この熱処理操作 (急熱・急冷) は自動車用低炭素薄鋼板でも焼入れによる強化が可能であることを示唆していた．この示唆は，工業用純鉄

$(0.013 \mathrm{mass} \% \mathrm{C})$ や極低炭素鋼（0.02mass\%C）の針金（いずれも直径 $1 \mathrm{~mm} ）$ を真空中で油焼入れすると，焼なま し状態のときに比べて, 引張り強さがかなり増大寸るという実験(3)によっても裏付けられる. 上にみたように, 従来は焼入れ強化の対象とされてこなかった極低炭素鋼でも，冷却速度を十分高めれば焼入れ強化が期待できる と考えられた．ところで，これまでも極低炭素鋼の焼入れ強化の研究は行われてきている．倉富らは ${ }^{(4)}$, 焼入れ 性を高めるための合金元素を添加した極低炭素鋼 $(0.04 \mathrm{mass} \% \mathrm{C})$ が焼入れによって強化し，焼入れのままで機械 部品に利用できることを示した，さらに，焼入れによって形成されたマルテンサイトには十分な可塑性があり塑 性変形 (ショット・ピーニングによる)を与えると加工硬化によって一層強度が増すことを示している. その後, 友田らも ${ }^{(5)}$, 合金元素を添加した低炭素鋼の焼入れままのマルテンサイト鋼について有益な知見を得ている.

本研究は, 高強度鋼板を用いる代わりに, 成形性の良い低炭素鋼板で作られるプレス成形部品に焼入れを施し てその部品を強化する一種の複合加工（プレス成形一焼入れ複合加工）の実用化を目指寸試みである. そのため に，まず，特別の合金元素を含まない深絞り用低炭素薄鋼板の高周波焼入れによる強化挙動を調査検討し，かな りの強化ができることを，主に引張試験により，また一部は曲げ試験を行って確認した.

\footnotetext{
* 原稿受付 2010 年 12 月 22 日

*1 正員, 広島国際学院大学工学部（干739-0321 広島県広島市安芸区中野 6-20-1）

*2 正員, (株)デルタツーリング（干736-0084 広島県広島市安芸区矢野新町 1-2-10）

*3 (株) デルタツーリング

${ }^{* 4}$ 正員, 永年会員, 広島大学名誉教授

E-mail: sumomogi@hkg.ac.jp
} 


\section{2. 実験方法}

\section{$2 \cdot 1$ 試料}

供試材料として，特別の合金元素を含まない自動車用極軟鋼薄板 SPCC/t1.0 と SPHC/t1.2 を用いた．ここで， $\mathrm{t}$ は板の厚さを表す（例えば 11.0 は板厚 $1.0 \mathrm{~mm}$ のこと）。これらを鋼 1 および鋼 2 とよぶことにする. 各鋼の化学 成分を表 1 に示すが，これはミルシート記載の值である.

Table 1 Chemical composition (mass\%) of steels from mill-sheets.

\begin{tabular}{|l|c|c|c|c|c|}
\hline steel & $\mathrm{C}$ & $\mathrm{Si}$ & $\mathrm{Mn}$ & $\mathrm{P}$ & $\mathrm{S}$ \\
\hline steel 1 (SPCC/t1.0) & 0.002 & 0.007 & 0.110 & 0.019 & 0.010 \\
\hline steel 2 (SPHC/t1.2) & 0.050 & 0.007 & 0.013 & 0.012 & 0.003 \\
\hline
\end{tabular}

\section{$2 \cdot 2$ 焼入れ処理}

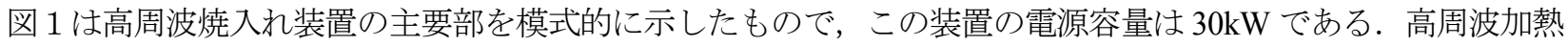
焼入れ（以後, 高周波焼入れという） は, 幅 $100 \mathrm{~mm}$, 長さ $300 \mathrm{~mm}$ に切断した鋼板の幅中心に長手方向に沿って 幅 $30 \mathrm{~mm}$ ，長さ $200 \mathrm{~mm}$ の領域に施した. 焼入れ時の冷却はジェット水の吹き付けによった. 鋼 1 と鋼 2 のいずれ についても，比較のために電気炉加熱による焼入れ（以後，電気炉焼入れという）も行った。この電気炉焼入れ は, 幅 $25 \mathrm{~mm}$, 長さ $150 \mathrm{~mm}$ の短冊に加工した鋼板を内径 $30 \mathrm{~mm}$ のカンタル線管状炉で加熱後水水中に投入して行 った. 試料の温度測定には, 高周波焼入れのときはサーモグラフィー, 電気炕焼入れのときはアルメルークロメル

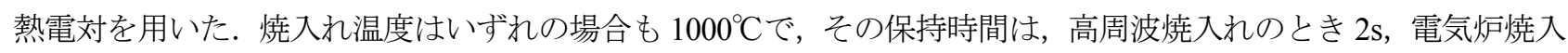
れのとき $180 \mathrm{~s}$ とした.

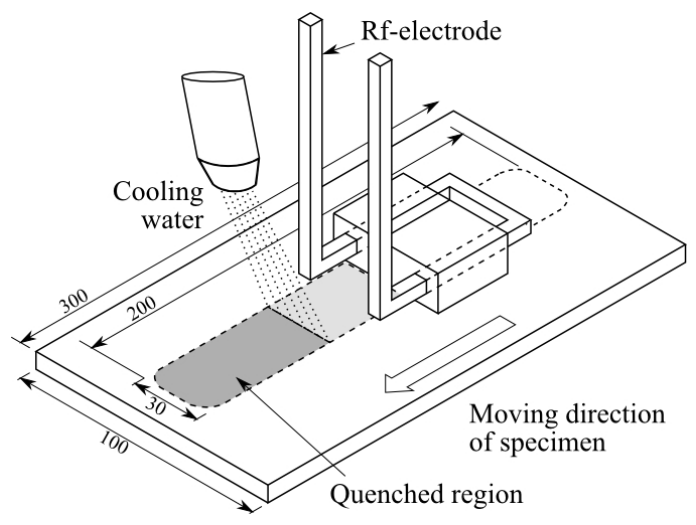

Fig. 1 Schematic illustration of induction heat quenching.

\section{$2 \cdot 3$ 引張試験および曲げ試験}

引張試験片は, 受入れままの板と焼入れした板からワイヤ放電加工により切り出して, 図 2 に示寸 JIS-Z2201 規格 13B 号の形状とした. 引張試験は, 精密万能試験機 AG-250kNG (島津製作所製) を用い, ひずみ速度 $1.4 \times 10^{-3} / \mathrm{s}$ で行った. 同一条件で 2 5 回の試験を行い, 公称応力一公称ひずみ曲線から引張強さと破断伸びを求めた.

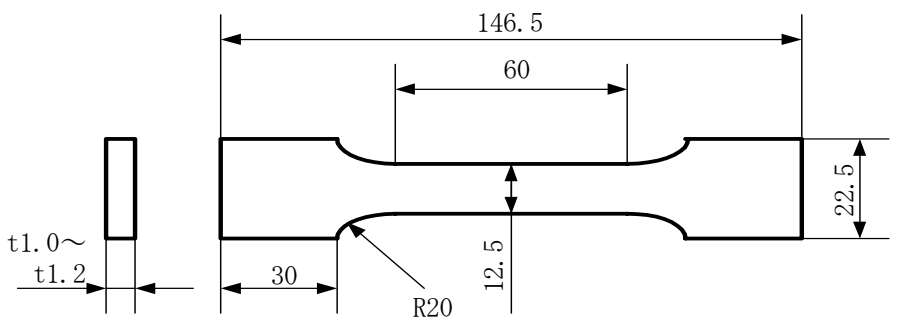

Fig. 2 Tensile specimen Type 13B (JIS-Z2201). 
鋼 1 については曲げ試験も行った．この試験は，幅 $100 \mathrm{~mm}$ ，長さ $200 \mathrm{~mm}$ の板を図 3 に示すような変則的な三 点曲げで行い，荷重一たわみ曲線を求めた。この変則的曲げを採用したのはプレス成形体の板面に対して直交成 分をもつ力が作用するとき（例えば，自動車に対して側方からの衝突など）の抵抗力やエネルギ一吸収能を評価 するのに便利であろうと考えたからである．曲げ試験片（100mm×200mm）は，受入れままの状態と試験片中央 に長手方向に沿い幅 $30 \mathrm{~mm}$ ，長さ $130 \mathrm{~mm}$ にわたり高周波焼入れした状態のものとした．この試料を間隔 $60 \mathrm{~mm} の$ 二支点で支え，その中央をポンチ押込み速度 $50 \mathrm{~mm} / \mathrm{min}(0.83 \mathrm{~mm} / \mathrm{s})$ で押し込んだ．燒入れ条件は引張試験片に 対するものと同じ $\left(1000^{\circ} \mathrm{C} ， 2 \mathrm{~s}\right.$ 保持後焼入れ）である.

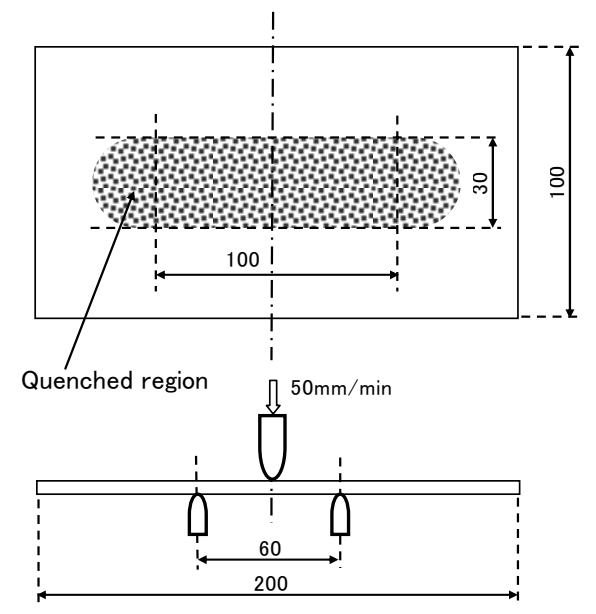

Fig. 3 Modified three-points bending.

\section{$2 \cdot 4$ ミクロ組織観察}

受入れままの試料と焼入れ後の試料のいずれも板表面に対する垂直断面を鏡面に仕上げ，その面を腐食液ピク ラール（5\%ピクリン酸アルコール溶液）でエッチングして後，光学顕微鏡で組織観察した.

\section{3. 実験結果と考察}

\section{3・1 引張試験結果}

図 4 と図 5 に，鋼 1 と鋼 2 の公称応力一公称ひずみ曲線（以後, 応力ーひずみ曲線とよぶ）をそれぞれ示す. これらの図には，いずれも受入れのまま，電気炉焼入れおよび高周波焼入れの試料の結果が示されている．両鋼 ともに，高周波焼入れ材は受入材に比べて，引張強さが約 $300 \mathrm{MPa}$ から約 $600 \mathrm{MPa}$ まで 2 倍程度まで著しく増加 している.ただし，破断伸びは約 40\%からほぼ半分の約 $20 \%$ ただ減少している.

比較のために調べた電気炉焼入れ試料の応力ーひずみ曲線も図 4 と図 5 に破線で示してある. 電気炉焼入れに よる強化は，高周波焼入れに比べて，鋼 1 では小さく，鋼 2 では同程度であった.

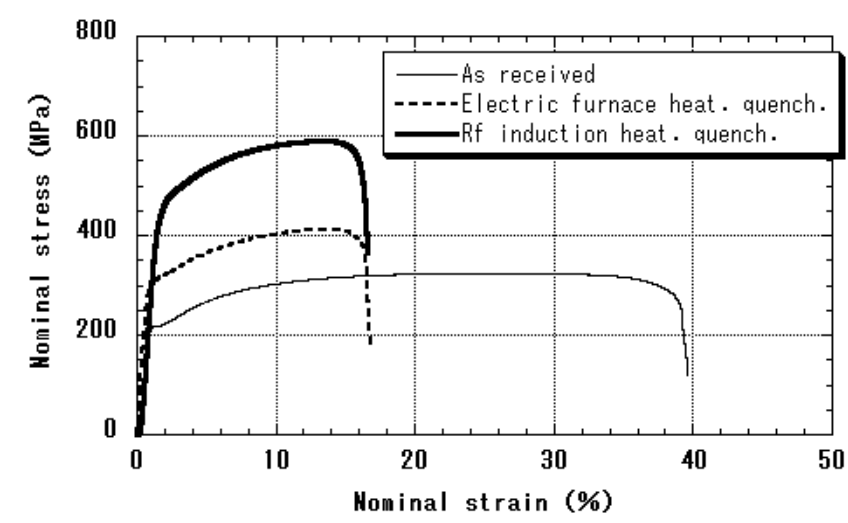

Fig. 4 Stress-strain curves of steel 1.

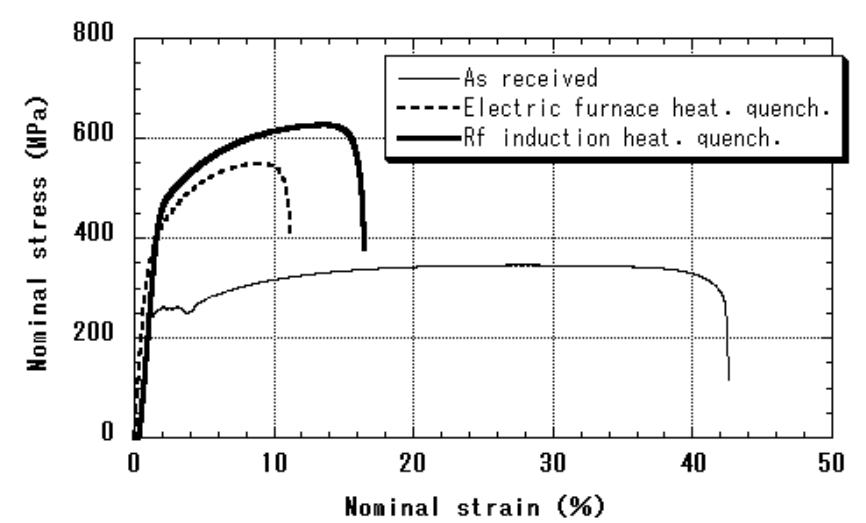

Fig. 5 Stress-strain curves of steel 2. 
特別な合金元素を添加していない極低炭素鋼でも焼入れによって，特に高周波焼入れによって著しく強化でき るという本実験の結果は，著者らの知る限りでは報告例を見ず，それゆえ実際的な利用例も見当たらない．上に みた焼入れ強化を認識しえたのは，今まで工業的要請がなかった薄鋼板の焼入れ，つまり薄板であるために冷却 速度が高まる焼入れ操作に著者らがたまたま遭遇したことによる．現在，引続き極低炭素鋼の焼入れ特性に及ぼ す焼入れ温度や泠却速度の影響を詳しく調査中である.

\section{$3 \cdot 2$ 組織観察}

図 6 に, 鋼 1 および鋼 2 の光学顕微鏡組織を示す，受入れのままでは，両鋼とも平均結晶粒径が $10 \mu \mathrm{m}$ 程度の 典型的なフェライト組織の等軸晶となっている. 高周波焼入れすると両鋼ともに結晶粒径 $1 \sim 3 \mu \mathrm{m}$ の微細な等軸 晶の結晶粒が $10 \mu \mathrm{m}$ 程度の結晶の粒界に分散した混粒組織となっている. 針状組織で特徵づけられる通常のマル テンサイト組織が認められなかったが，その理由はいまのところ不明である．高周波により短時間（1s 程度）加 熱後焼入れした $\mathrm{S} 45 \mathrm{C}$ 鋼においても結晶粒の微細化が起こるという報告( ${ }^{(6)}$ があることを考えると，本実験でみた 細粒化現象は広範な鋼で起こることかも知れず今後の検討課題としたい.

一方，電気炉焼入れ寸ると，両鋼ともに数 $10 \mu \mathrm{m}$ のパケット粒界の中にブロックおよびラスが存在するラスマ ルテンサイト組織となっている，マルテンサイト組織の鋼にもかかわらず，図 4 と図 5 に示す応力ーひずみ曲線 (破線) にみるように，10２0\%もの破断伸びがあるという本実験結果は，すでに指摘されているように(4)(5)， 低炭素マルテンサイト鋼は脆くはなくかなり延性に富むことを示している.

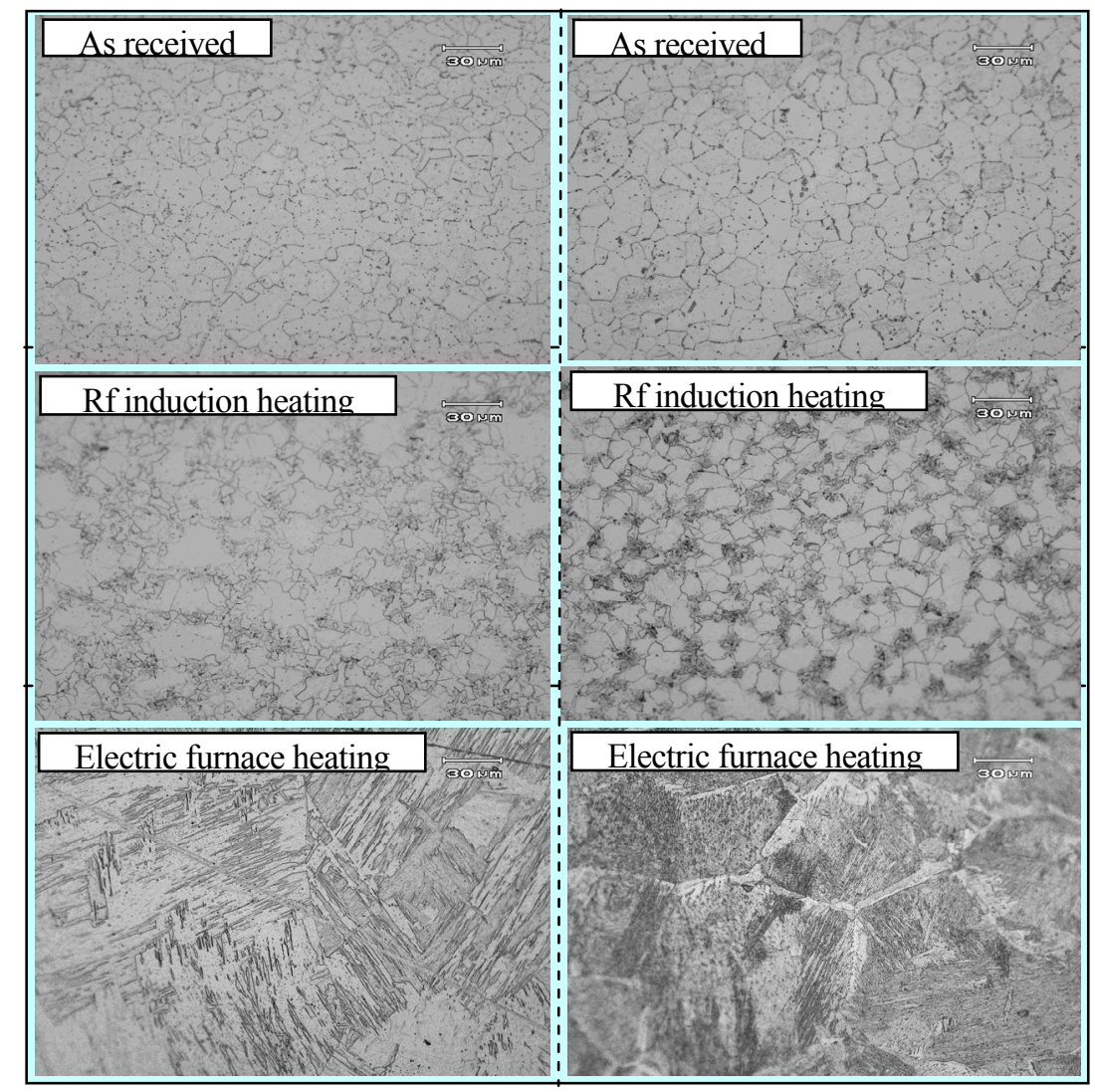

Fig. 6 Microstructures of steel 1 (left) and steel 2 (right).

\section{$3 \cdot 3$ 曲げ試験結果}

図 3 に示寸変則的三点曲げ試験を鋼 1 について行って得られた荷重一たわみ曲線を図 7 に示す.この結果は, 板の一部を高周波焼入れするだけでいかに曲げ強さが増大するかをよく表している．また，部分焼入れされた鋼 板が焼入れ箇所も曲げ変形に十分耐えられるので大きいエネルギー吸収能をもつことを示している.

加工性の良い従来の極低炭素鋼板を用いれば複雑な形状のプレス加工が可能であるが，難点は，前述したよう に，成形体の強度が小さい上に衝撃力などを受けた際におけるエネルギー吸収能が小さいことである. しかし， 
本実験結果から，極低炭素鋼板のプレス成形体の適当な部分に高周波焼入れを施せば，その成形体の強度とエネ ルギー吸収能を大幅に増加させ得るものと期待できる. 事実, 著者らはそのことを実用に供している(7)(8).ただし, この場合焼入れによって生じる変形を矯正するか，あるいは，この変形が生じにくい構造設計を考慮する必要が ある. さらに，焼入れ条件（焼入れ温度とその温度の保持時間）を制御することにより焼入れ強化の程度を变え ることもできるが，その詳細については改めて報告する予定である.

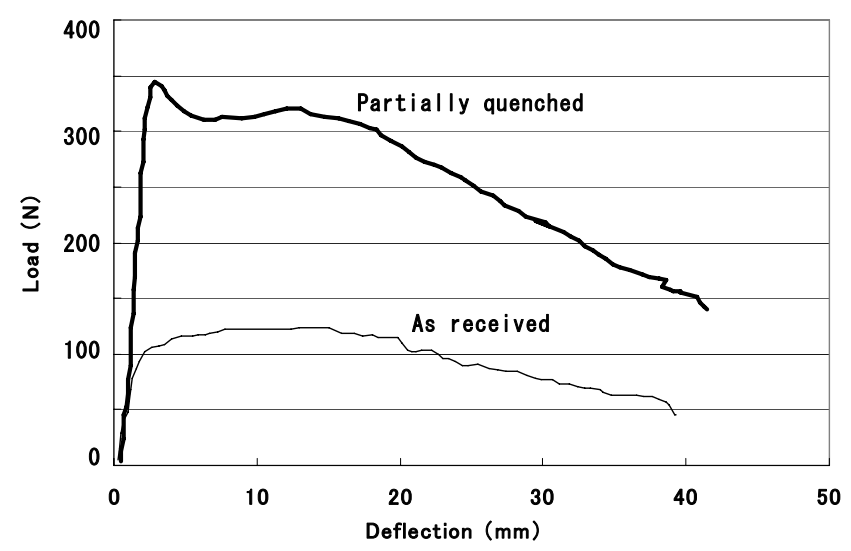

Fig. 7 Load-deflection curves of steel 1 sheet.

\section{4. 結 論}

従来から使われてきているプレス加工性の良い二種類の自動車用極低炭素薄鋼板（SPCC 鋼板と SPHC 鋼板） の高周波焼入れ挙動（高速短時間加熱後焼入れ挙動）を調べ, 以下の結果を得た.

（1） 高周波焼入れ $\left(1000^{\circ} \mathrm{C} ， 2 \mathrm{~s}\right.$ 加熱）によって, 引張強さは著しく増加した．ただし，破断伸びは低下した。 通常の電気炉焼入れ，すなわち緩速長時間加熱後焼入れ $\left(1000^{\circ} \mathrm{C}, 180 \mathrm{~s}\right.$ 加熱）によっても強化するが，そ の強化の程度は高周波焼入れの場合には若干及ばない.

(2) 高周波焼入れによって生じるミクロ組織は微細粒を伴う混粒で等軸晶の組織であった。電気炉焼入れでは 典型的なマルテンサイト組織となった.

（3）鋼板の一部を高周波焼入れすると，その曲げ変形時の強度ならびにエネルギー吸収能が高まった．このこ とは，鋼板プレス成形体の適当な部分に高周波焼入れを施すことによって，その成形体の強度とエネルギ 一吸収能を高める一種の複合加工技術開発の有用性を示唆している.

おわりに，低炭素鋼の焼入れに関する研究と実用の現状について，新日本製鉄（株）技術顧問（京都大学名誉 教授）の牧正志先生から種々貴重な意見をいただいた。ここに厚く御礼申し上げます.

\section{文 献}

（1）古原忠，大澤紘一，古君修 監修，“自動車用ハイテン”, JFE21 世紀財団 (2008).

(2) 薄鋼板成形技術研究会, “プレス成形難易ハンドブック第 3 版”, 日刊工業新聞社 (2007).

(3) 作井誠太，大森正信，“純鉄の衝撃引張試験”，鉄と鋼，45-4 (1959), pp. 415-423.

（4）倉冨英明, 高橋正清, 伯者田毅, 堀健一, 村上陽一, 露木伸一, “新型 V6 ツインカム VQ 型エンジン用コネ クティングロッドの開発”, 自動車技術会学術講演会前刷集 946 (1994), pp.185-188.

（5）友田陽，青山誠，竹中正鋭，倉富英明，谷本一郎，“焼入れままの低炭素マルテンサイト鋼の利用に関する 基礎的検討”，日本機械学会論文集(A 編)，62-599 (1996), pp.1605-1612.

（6）福田忠生，中島大剛，江田潤一，黒島義人，三坂佳孝，川蔏一博，“誘導加熱を用いた超急速短時間焼戻鋼 の引張特性”, 日本機械学会論文集(A 編), 73-726 (2007), pp.285-291.

(7) 李木経孝, 吉田誠也, 高田康秀, 藤田悦則, 大森正信, “低炭素鋼板の加工熱処理に関する研究”, 日本金属学会中 四国支部金属第 46 回講演大会講演概要 (2006), pp. 63.

（8）藤田悦則，高田康秀，我田茂樹，李木経孝，“低炭素金属部材を用いた高強度金属部材及びその製造法”，特 願 2006-188730. 